\title{
Associative Study of Individual Characteristics, Information Accessibility and Media Literation with Agricultural Information through Whatsapp: Exploration on Mango Farmers in Pasuruan Regency
}

\author{
Wahyu Santoso, Teguh Soedarto and Hamidah Hendrarini
}

\section{ABSTRACT}

\begin{abstract}
Information in agriculture has an important role for farmers in efforts to improve their farming activities. Some empirical research on the use of WhatsApp as a medium for disseminating information among farmers is still limited even though farmers have used it. This study explores the use of WhatsApp in strengthening agricultural information for mango farmers in Pasuruan Regency. The data analysis method used consists of two stages, the first is Crosstab, the second stage is measuring the association is Chi-Square using IBM SPSS Ver software. 23. The results of the analysis show that the age of the respondent is the only factor that is stated to have no relationship with agricultural information via WhatsApp. While other factors forming individual characteristics, namely education, length of time using HP, and length of farming have a relationship with agricultural information via WhatsApp. The four factors that make up the accessibility of information consist of completeness of features, icons/images that are easy to remember $\&$ find, ease of navigation and attractive appearance/interface, all of which are stated to have a relationship with agricultural information via WhatsApp. In addition, the research findings provide an interesting picture, namely sending and downloading agricultural info videos is the only media literacy factor that is stated to have no relationship with agricultural information via WhatsApp. Meanwhile, other factors forming Media Literacy, namely Sending messages/chats and calls, Time to find Information and Discussions on WA Group have a relationship with agricultural information via WhatsApp.
\end{abstract}

Keywords: Accessibility of Information, Individual Characteristics of Farmers, Media Literacy, and WhatsApp.

\section{INTRODUCTION}

World civilization in the current era of disruption indirectly shapes the information society. In principle, in the information society the need for information becomes an absolute necessity where information becomes a commodity of economic value and strategic meaning. The emergence of social media is evidence of the rapid development of computer and internet technology, starting from Friendster in 2002, LinkedIn in 2003. MySpace in 2003, Facebook in 2004, Youtube in 2005, Twitter in 2006, WhatsApp in 2009, Instagram in 2010, Google+ in 2011, and Line in 2011. Its presence as a necessity in today's digital era is like two blades. According to [1] social media is a medium on the internet that allows users to represent themselves and interact, cooperate, share, communicate with other users to form virtual social bonds.

WhatsApp have seen a dramatic growth, with reports suggesting an increase of up to 1 million users per day, reaching a number of 600 million users in 2014 with a daily engagement higher than the industry standard [2]. A study of We Are Social in year 2018 as a British media company shows that the most in demand social media chat/messenger today is WhatsApp. WhatsApp is one of the popular social
Submitted : October 28, 2021

Published : December 28, 2021

ISSN: $2684-1827$

DOI: $10.24018 /$ ejfood.2021.3.6.401

\section{Wahyu Santoso*}

Department of Agribusiness, Faculty of Agriculture, University of Pembangunan Nasional "Veteran", Indonesia.

(e-mail: wahyu.agri@upnjatim.ac.id) Teguh Soedarto

Departement of Agribusiness, Faculty of Agriculture, University of Pembangunan Nasional "Veteran", Indonesia.

Hamidah Hendrarini

Electrical Engineering Department, Departement of Agribusiness, Faculty of Agriculture, University of Pembangunan Nasional "Veteran", Indonesia.

*Corresponding Author media because of its ease of use compared to other social media. WhatsApp makes it easy to convey messages or information in an effective and time efficient manner [3]-[5]. Some of the features available on the WhatsApp application include Group Chat, WhatsApp on the web and desktop, WhatsApp Voice and video calls, end-to-end encryption, sending photos and videos, voice messages, and documents. The group chat feature, for example, can be used by members of farmer group associations to communicate and discuss through social media and disseminate other information related to agriculture [6].

Dissemination of agricultural information in mango farmers group before the existence of social media is carried out conventionally, through of personal communication by visiting the location of information sources (farmers, extension agents and traders) and group communication in the form of farmer group meetings or discussions with the schedule has been determined and sometimes problems such as jealousy towards other farmer groups arise. This has an impact on the delay in information needed by farmers, thus hampering farming activities. Even, the marketing of mango fruit is very profitable with the uniqueness taste of its products that are in demand. [3], [7] stated WhatsApp to open up new opportunities for intimate communication for farm 


\section{communities.}

Several previous studies regarding the use of WhatsApp as a medium for disseminating information among farmers are still rare, especially the use of WhatsApp as a medium for disseminating agricultural information to farmer groups. Searching for scientific articles conducted [8] with a research focus on knowing the effectiveness of communication using rice farming technology, concludes that the use of sources and channels of information on radio frequency indicators has a very positive relationship with communication effectiveness. [4] argue that the use of media is very important in the context of adopting innovation by the main fisheries actors. Therefore, it is known that external factors in the presentation of extension media are closely related to the use of extension media in the form of leaflets, outcrop maps and magazines. [8] provide research findings that farmers in Gweru District, Zimbawe prefer stimulating and interesting media such as television and demonstrations because the majority of them have never attended training in agriculture.

Moreover, the World's Most Literate Nations in year 2019 research mentions an interesting fact that the literacy ability of the Indonesian population is very low. Indonesia is ranked 60 th out of 61 countries on various continents. There are six basic literacies that adults must master according to the World Economic Forum, namely literacy, numeration literacy, financial literacy, science literacy, cultural literacy and digital literacy (media). In addition, statistics from the [9] show that the majority of farmers in Indonesia have a low level of education, which is only up to elementary school level. There were 37.53 percent of elementary school graduates, 24.23 percent did not finish elementary school, 16.83 percent finished high school, 8.98 percent finished high school, 7.19 percent did not attend school, 3.78 percent finished high school, and 1.47 percent graduated from higher education. Low education causes knowledge in agricultural processing to be undeveloped and monotonous. Farmers only process agriculture as usual without creating new innovations to increase agricultural production, this also leads to the slow adoption of agricultural technology in farmers [8]. Farmers in Indonesia are in desperate need of education or deeper knowledge about agricultural activities. Based on this, the purpose of the research is analyzing the relationship between individual farmer characteristics, information accessibility, media literacy and agricultural information on mango farmers groups in Pasuruan Regency.

\section{RESEARCH METHODS}

\section{A. Location}

The location of this research is a mango cultivation center village in Rembang District, Pasuruan Regency, East Java Province. The selection of the research area was done because there is still a lot of high potential for manga cultivation and many farmers are starting to use WhatsApp in line with the development of mobile phones.

\section{B. Sample}

Determination of the sample in the study was carried out on members of the Mango Farmer's Group in Rembang District. Based on the recap of the farmer group, it is known that there are 80 active members. The sample of farmers was taken using purposive sampling method where the sample selection was deliberately based on considerations of the interests or objectives of the study to obtain complete and indepth information with the following criteria: 1. Farmers with productive age 30-45 years and technology literate, and 2. Experience Mango farming for at least 2 years, based on these criteria 35 respondents were used for the sample.

\section{Data Analyzed}

This study uses the Chi-Square method. A crosstab is a cross table consisting of one or more rows and one or more columns. This analysis technique was carried out using the IBM SPSS Ver. 23. The displayed crosstab is a cross tabulation between individual characteristics of farmers, accessibility of information, media literacy to agricultural information of mango farmers. While the statistical tool that is often used to measure associations in a crosstab is ChiSquare. The method that is the basis for decision making in the Chi-Square method in this study is based on probability (significance). If the probability $>0.05$ then there is no relationship between the variables on the crosstab. Meanwhile, if the probability is $<0.05$ then there is a relationship between the variables in the crosstab [10].

\section{RESUlT AND DISCUSSION}

\section{A. Relationship of Individual Farmer Characteristics with Agricultural Information via WhatsApp}

Farmers as human beings who live in society, have the freedom to interact with the surrounding environment, learn new things, and follow any existing developments. This will shape the characteristics of farmers related to their level of competence in farming. These characteristics will reflect behavior that describes the motivation, personal characteristics, self-concept, values, knowledge, or skills brought by someone who excels in farming. The age of the farmer is the age of the farmer at the time of the research which is expressed in years. Age is related to physical strength, enthusiasm, experience, and adoption rate of using WhatsApp to seek and receive agricultural information. Based on Table I. it can be seen that the relationship between the age factor and agricultural information. Farmers aged 2035 years mostly answered Agree (7 people) if through WhatsApp they could support Agricultural Information. In addition, the results also showed that farmers who had an age range of 36-51 years also agreed to agree that WhatsApp supports Agricultural Information, knowing that 10 respondent farmers answered that way. Farmers in the productive category tend to have ease in accepting new things, including on farm cultivation.

A classic problem where the Indonesian agricultural sector is still constrained by the still low level of education of the farmers, the majority of their education is elementary school graduates, so it is not surprising that agricultural production is less highly competitive.

Even though the agricultural potential is so great if the education system and higher level of knowledge of farmers are believed to be able to increase agricultural productivity [11]. On the other hand, agriculture will get added value as a bonus from knowledge and skills that are increasingly honed so as to be able to prosper the farmers. 
TABLE I: RELATIONSHIP BETWEEN AGE FACTORS AND AGRICULTURAL INFORMATION

\begin{tabular}{|c|c|c|c|c|c|}
\hline \multicolumn{6}{|c|}{ INFORMATION } \\
\hline & \multirow[t]{3}{*}{ Count } & \multicolumn{3}{|c|}{ Crosstab } & \\
\hline & & \multicolumn{3}{|c|}{ Agricultural Information } & \multirow[b]{2}{*}{ Total } \\
\hline & & Disagree & Agree & $\begin{array}{c}\text { Strongly } \\
\text { Agree }\end{array}$ & \\
\hline \multirow{4}{*}{ Ages } & 20-35 Year & 1 & 7 & 2 & 10 \\
\hline & 36-51 Year & 1 & 10 & 5 & 16 \\
\hline & $>51$ Year & 3 & 3 & 3 & 9 \\
\hline & Total & 5 & 20 & 10 & 35 \\
\hline
\end{tabular}

Source: Data Analysis (2021).

TABLE II: RELATIONSHIP BETWEEN EDUCATIONAL FACTORS AND

\begin{tabular}{|c|c|c|c|c|c|}
\hline \multicolumn{6}{|c|}{ AGRICULTURAL INFORMATION } \\
\hline & \multirow{3}{*}{ Count } & \multicolumn{3}{|c|}{ Crosstab } & \multirow{3}{*}{ Total } \\
\hline & & \multicolumn{3}{|c|}{ Agricultural Information } & \\
\hline & & Disagree & Agree & Strongly Agree & \\
\hline \multirow{3}{*}{ Education } & Primary School & 3 & 4 & 2 & 9 \\
\hline & $\begin{array}{l}\text { Senior High } \\
\text { School }\end{array}$ & 1 & 10 & 6 & 17 \\
\hline & $\begin{array}{c}\text { junior high } \\
\text { school }\end{array}$ & 1 & 6 & 2 & 9 \\
\hline \multicolumn{2}{|r|}{ Total } & 5 & 20 & 10 & 35 \\
\hline
\end{tabular}

Based on Table II. it can be seen that the majority of farmers with high school graduates agreed that the existence of WhatsApp was able to provide agricultural information, that is, it was known that 10 people answered that way. Four farmers, known as elementary school graduates, also agreed that WhatsApp was useful for seeking or receiving agricultural information. This is also in line with research [4], [17] which concludes that the level of education contributes to the development of farmers' knowledge in technology adoption.

This is different from the results of the research which correlates the length of time using mobile phones with agricultural information via WhatsApp, which is shown in Table III. Farmers who have had mobile phones for more than 2 years have agreed that agricultural information can be obtained through WhatsApp, as many as 17 respondents. While 7 people answered strongly agree with the same statement. An interesting finding in this study is that there is 1 farmer respondent who disagrees if agricultural information via WhatsApp is not related to the length of use of HP. This means that the respondent's criteria feel because the cellphones they have bought or have just used have not had great benefits for their agricultural activities.

Exploration of the relationship between the length of farming factor and agricultural information via WhatsApp is described in Table 4. Based on Table IV. it can be seen that the majority of farmers with farming duration $>5$ years $(17$ people) answered agree that the length of farming has a relationship with agricultural information via WhatsApp. Only 1 respondent is known to strongly agree with the farmer's statement with less than a year of farming.

TABLE III: THE RELATIONSHIP BETWEEN OLD FACTORS USING HAND PHONE WITH AGRICULTURAL INFORMATION

\begin{tabular}{|c|c|c|c|c|c|}
\hline \multicolumn{6}{|c|}{ PHONE WITH AGRICULTURAL INFORMATION } \\
\hline \multirow[t]{3}{*}{ Count } & & \multicolumn{4}{|c|}{ Crosstab } \\
\hline & & \multicolumn{3}{|c|}{ Agricultural Information } & \multirow[b]{2}{*}{ Total } \\
\hline & & Disagree & Agree & $\begin{array}{l}\text { Strongly } \\
\text { Agree }\end{array}$ & \\
\hline \multirow{3}{*}{$\begin{array}{l}\text { Long Using Hand } \\
\text { Phone }\end{array}$} & $<1$ Year & 1 & 1 & 3 & 5 \\
\hline & $>2$ Year & 3 & 17 & 7 & 27 \\
\hline & 1-2 Year & 1 & 2 & 0 & 3 \\
\hline Total & & 5 & 20 & 10 & 35 \\
\hline
\end{tabular}

Source: Data Analysis (2021).
TABLE IV: THE RELATIONSHIP BETWEEN FARMING TIME FACTORS AND

\begin{tabular}{|c|c|c|c|c|c|}
\hline & \multirow[t]{3}{*}{ Count } & \multicolumn{3}{|c|}{ Crosstab } & \multirow{3}{*}{ Total } \\
\hline & & \multicolumn{3}{|c|}{ Agricultural Information } & \\
\hline & & Disagree & Agree & Strongly Agree & \\
\hline \multirow{3}{*}{$\begin{array}{l}\text { Long time } \\
\text { farming }\end{array}$} & $<1$ Year & 0 & 0 & 1 & 1 \\
\hline & $>5$ Year & 4 & 17 & 6 & 27 \\
\hline & 3-5 Year & 1 & 3 & 3 & 7 \\
\hline \multicolumn{2}{|c|}{ Total } & 5 & 20 & 10 & 35 \\
\hline
\end{tabular}

Source: Data Analysis (2021).

TABLE V: CHI SQUARE ANALYSIS OF INDIVIDUAL CHARACTERISTICS WITH AGRICULTURAL INFORMATION

\begin{tabular}{|c|c|c|c|}
\hline \multirow[b]{2}{*}{ No. } & \multirow[b]{2}{*}{$\begin{array}{l}\text { Relationship between } \\
\text { Research Variable }\end{array}$} & \multirow{2}{*}{$\begin{array}{c}\text { Pearson Chi-Square } \\
\text { Asymptotic } \\
\text { Significance (2- } \\
\text { sided) }\end{array}$} & \multirow[b]{2}{*}{ Justification } \\
\hline & & & \\
\hline 1. & $\begin{array}{l}\text { Age * Agricultural } \\
\text { Information }\end{array}$ & 0.312 & not relate \\
\hline 2. & $\begin{array}{c}\text { Education * Agricultural } \\
\text { Information }\end{array}$ & 0.039 & relate \\
\hline 3. & $\begin{array}{l}\text { Long Using Hand Phone * } \\
\text { Agricultural Information }\end{array}$ & 0.027 & relate \\
\hline 4. & $\begin{array}{c}\text { Long time farming } * \\
\text { Agricultural Information }\end{array}$ & 0.034 & relate \\
\hline
\end{tabular}

Source: Data Analysis (2021).

Furthermore, a chi square analysis of individual characteristics research variables was carried out with agricultural information via WhatsApp. The results of the analysis can be known by looking at the significance value approach. The age of the respondent is the only factor that is stated to have no relationship with agricultural information via WhatsApp because the significance value is greater than the level of $=5 \%(0.05)$ of $0.312<0.05$. While other factors forming individual characteristics, namely education, length of time using HP, and length of farming have a relationship with agricultural information via WhatsApp.

\section{B. Relationship of Information Accessibility with Agricultural Information via WhatsApp}

WhatsApp is now the most popular application. The ease and completeness of its features make WhatsApp have many users. Over time, WhatsApp also developed the features in it. Currently WhatsApp can not only be used to send messages, but can also make calls, send voices, and make video calls. The results of the analysis of the relationship between information accessibility and indicators of completeness of features with agricultural information via WhatsApp. Based on Table 6. it can be seen that farmers who stated 'Knowing' that WhatsApp has full features while answering 'Agree' full features of Whatsapp support search agricultural information, namely as many as 14 respondent farmers answered so. [13] stated that WhatsApp is a messaging application connected to the internet that aims to make it easier for users, namely farmers, to communicate through various available features.

The results are similar to the opinion of the respondent farmers as many as 14 people gave the statement 'Knowing' and 'Agree' if the WhatsApp Icon/Image is easy to remember and is found to support the process of searching for agricultural information (Table VII). In line with the ease of navigation between features, respondent farmers stated 'Very Knowing' and also 'Strongly Agree' if the attribute of the statement was associated with the agricultural information search process, namely 11 respondent farmers answered (Table VIII). 
TABLE V: THE RELATIONSHIP BETWEEN FULL-FEATURED WHATSAPP WITH AGRICULTURAL INFORMATION

\begin{tabular}{llccc}
\hline Count & \multicolumn{3}{c}{ Crosstab } \\
\hline & & Agricultural Information & \multirow{2}{*}{ Total } \\
\cline { 2 - 4 } & & Agree & Strongly Agree & \\
\hline WhatsApp has & Do not know & 2 & 1 & 3 \\
full features & Knowing & 14 & 2 & 16 \\
& Very Knowing & 5 & 11 & 16 \\
\hline Total & & 21 & 14 & 35 \\
\hline
\end{tabular}

Source: Data Analysis (2021).

TABLE VII: RELATIONSHIP BETWEEN WHATSAPP ICONS/IMAGES EASY TO REMEMBER AND FIND WITH AGRICULTURAL INFORMATION

\begin{tabular}{|c|c|c|c|c|}
\hline \multirow[t]{3}{*}{ Count } & & & rosstab & \multirow{3}{*}{ Total } \\
\hline & & \multicolumn{2}{|c|}{$\begin{array}{l}\text { Agricultural } \\
\text { Information }\end{array}$} & \\
\hline & & Agree & $\begin{array}{c}\text { Strongly } \\
\text { Agree }\end{array}$ & \\
\hline \multirow{3}{*}{$\begin{array}{l}\text { WhatsApp } \\
\text { icons/images are } \\
\text { easy to remember } \\
\text { to find }\end{array}$} & Do not know & 1 & 1 & 2 \\
\hline & Knowing & 14 & 2 & 16 \\
\hline & Very Knowing & 6 & 11 & 17 \\
\hline Total & & 21 & 14 & 35 \\
\hline
\end{tabular}

Source: Data Analysis (2021).

TABLE VIII: WHATSAPP HAS EASY NAVIGATION BETWEEN FEATURES WITH AGRICULTURAL INFORMATION

\begin{tabular}{|c|c|c|c|c|}
\hline \multirow[t]{3}{*}{ Count } & & \multicolumn{3}{|c|}{ Crosstab } \\
\hline & & \multicolumn{2}{|c|}{$\begin{array}{l}\text { Agricultural } \\
\text { Information }\end{array}$} & \multirow[b]{2}{*}{ Total } \\
\hline & & Agree & $\begin{array}{c}\text { Strongly } \\
\text { Agree }\end{array}$ & \\
\hline \multirow{3}{*}{$\begin{array}{l}\text { WhatsApp has easy } \\
\text { navigation }\end{array}$} & Do not know & 6 & 2 & 8 \\
\hline & Knowing & 12 & 1 & 13 \\
\hline & Very Knowing & 3 & 11 & 14 \\
\hline \multicolumn{2}{|l|}{ Total } & 21 & 14 & 35 \\
\hline
\end{tabular}

Source: Data Analysis (2021).

TABLE IX: THE RELATIONSHIP BETWEEN WHATSAPP HAS A Q GENERAL APPEARANCE/INTERFACE INTERESTING WITH AGRICULTURAL

\begin{tabular}{llccc}
\multicolumn{3}{c}{ INFORMATION } \\
\hline Count & \multicolumn{3}{c}{ Crosstab } \\
& & \multicolumn{2}{c}{$\begin{array}{c}\text { Agricultural } \\
\text { Information }\end{array}$} & \\
\cline { 3 - 4 } & & Total \\
& & Agree & $\begin{array}{c}\text { Strongly } \\
\text { Agree }\end{array}$ & \\
\hline WhatsApp has an & Do not know & 2 & 2 & 4 \\
attractive & Knowing & 15 & 1 & 16 \\
appearance/interface & Very Knowing & 4 & 11 & 15 \\
\hline Total & & 21 & 14 & 35 \\
\hline
\end{tabular}

Source: Data Analysis (2021).

TABLE X: CHI SQUARE ANALYSIS OF INFORMATION ACCESSIBILITY WITH AGRICULTURAL INFORMATION

\begin{tabular}{|c|c|c|c|}
\hline \multirow[b]{2}{*}{ No. } & \multirow[b]{2}{*}{$\begin{array}{l}\text { Relationship between } \\
\text { Research Variable }\end{array}$} & \multirow{2}{*}{$\begin{array}{c}\text { Pearson Chi-Square } \\
\text { Asymptotic } \\
\text { Significance (2- } \\
\text { sided) }\end{array}$} & \multirow[b]{2}{*}{ Justification } \\
\hline & & & \\
\hline 1. & $\begin{array}{l}\text { WhatsApp has full features } \\
* \text { Agricultural Information }\end{array}$ & 0,005 & relate \\
\hline 2. & $\begin{array}{l}\text { WhatsApp icons/images } \\
\text { are easy to remember to } \\
\text { find } * \text { Agricultural } \\
\text { Information }\end{array}$ & 0.009 & relate \\
\hline 3. & $\begin{array}{l}\text { WhatsApp has easy } \\
\text { navigation * Agricultural } \\
\text { Information }\end{array}$ & 0,001 & relate \\
\hline 4. & $\begin{array}{l}\text { WhatsApp has an attractive } \\
\text { appearance/interface * } \\
\text { Agricultural Information }\end{array}$ & 0,001 & relate \\
\hline
\end{tabular}

Based on the results of the analysis, it can be seen that as many as 15 respondent farmers have been identified in the 'Knowing' and 'Agree' groups if WhatsApp has an attractive appearance/interface to support the process of searching for agricultural information (Table IX). Furthermore, a chi square analysis of the research variables of information accessibility with agricultural information was carried out via WhatsApp. The results of the analysis can be known by looking at the significance value approach. Based on the four factors proposed in this study, consist of full features, easy to remember and find icons/images, ease of navigation and general appearance/interface, all of them stated that there was a relationship with agricultural information via WhatsApp because the significance value was less than the level of $=5 \%$ (0.05) (Table X). Thus, accessibility of information is a top priority for mango farmers in finding, obtaining and applying agricultural information using WhatsApp media.

\section{Relationship between Media Literacy and Agricultural Information via WhatsApp}

Media literacy is basically the ability to understand and apply. The ability to do this is intended so that media consumers become aware (literate) of the way media is constructed and accessed [14]. Based on Table XI. it can be seen that as many as 12 respondent farmers gave $<3$ times and 'Agree' on the association between sending messages/chats and WhatsApp calls with Agricultural Information. Meanwhile, from a total of 35 respondents, it can be seen that those who answered 1-2 hours from the Time of Seeking Information with WhatsApp supported the process of searching for agricultural information, at least 8 farmers answered 'Agree'. Therefore, more than one workday is spent on the phone each week, with several hours using WhatsApp only. Considering a growing body of scientific observations showing that humans spend time on their smartphones and the Internet mostly for leisure, rather than business purposes [15], [7]. In contrast to the case, with the results of the analysis which stated that as many as 3 respondent farmers answered 'Strongly Agree' (Table XIII) if agricultural information was sourced from sending and downloading agricultural info videos. This means that a farmer can act as a communicant (message recipient) as well as a communicator (message recipient).

TABLE XI: RELATIONSHIP BETWEEN SENDING MESSAGES/CHATS AND WHATSAPP CALLS WITH AGRICULTURAL INFORMATION

\begin{tabular}{ccccc}
\hline \multicolumn{2}{c}{ Count } & \multicolumn{3}{c}{ Crosstab } \\
\hline & & Agricultural Information & \multirow{2}{*}{ Total } \\
\cline { 2 - 4 } & Agree & Strongly Agree & \\
\hline Send WhatsApp & $<3$ times & 12 & 9 & 21 \\
messages/chats \& & $>5$ times & 4 & 1 & 5 \\
calls in a Day & $3-5$ times & 5 & 4 & 9 \\
\hline \multicolumn{2}{c}{ Total } & 21 & 14 & 35 \\
\hline Source: Data Analysis (2021). & & &
\end{tabular}

\begin{tabular}{|c|c|c|c|c|}
\hline \multicolumn{2}{|l|}{ Count } & \multicolumn{3}{|c|}{ Crosstab } \\
\hline & & \multicolumn{2}{|c|}{ Agricultural Information } & \multirow{2}{*}{ Tota } \\
\hline & & Agree & Strongly Agree & \\
\hline Time to Find & $<1$ hour & 8 & 2 & 10 \\
\hline Information with & $>2$ hour & 5 & 5 & 10 \\
\hline WhatsApp & 1-2 hour & 8 & 7 & 15 \\
\hline Total & & 21 & 14 & 35 \\
\hline
\end{tabular}

Source: Data Analysis (2021). 
TABLE XIII: SENDING AND DOWNLOADING AGRICULTURAL INFO WITH AGRICULTURAL INFORMATION

\begin{tabular}{ccccc}
\hline Count & \multicolumn{4}{c}{ Crosstab } \\
\hline & & Agricultural Information & \multirow{2}{*}{ Total } \\
\cline { 2 - 4 } & & Agree & Strongly Agree & \\
\hline Submitting and & $<3 \mathrm{kali}$ & 12 & 7 & 19 \\
Downloading Farm Info & $>5 \mathrm{kali}$ & 7 & 4 & 11 \\
Videos & $3-5 \mathrm{kali}$ & 2 & 3 & 5 \\
\hline Total & & 21 & 14 & 35 \\
\hline
\end{tabular}

Source: Data Analysis (2021).

The research findings also show an interesting thing that as many as 10 respondents participating in the WA Group Discussion in a Month stated 'Agree; the discussion became a supporting tool for obtaining agricultural information (Table XIV). A chi square analysis of media literacy research variables with agricultural information was carried out via WhatsApp. The results describe Sending and Downloading Agricultural Info Videos is the only media literacy factor which is stated to have no relationship with agricultural information via WhatsApp because the significance value is greater than the level of $=5 \%(0.05)$ of $0.615<0.05$. Meanwhile, other factors forming Media Literacy, namely Sending messages/chats \& Calls, Time to Find Information and Discussions, and Participate in WA Group Discussions in a month have a relationship with agricultural information via WhatsApp. WhatsApp is a mobile instant messaging application that enables quick, interactive multimedia oneon-one communication, as well as communication in closed, members-only groups [16].

TABLE XIV: FOLLOWING THE WA GROUP DISCUSSION WITH AGRICULTURAL INFORMATION

\begin{tabular}{ccccc}
\hline Count & \multicolumn{3}{c}{ Crosstab } \\
\hline & & Agricultural Information & \\
\cline { 3 - 4 } & & Agree & $\begin{array}{c}\text { Strongly } \\
\text { Agree }\end{array}$ & \\
\hline & $<3$ times & 10 & 6 & 16 \\
Participate in WA Group & $<5$ times & 3 & 2 & 5 \\
Discussions in a Month & $>5$ times & 1 & 3 & 4 \\
& $3-5$ times & 7 & 3 & 10 \\
\hline Total & & 21 & 14 & 35 \\
\hline
\end{tabular}

Source: Data Analysis (2021).

TABLE XV: CHI SQUARE ANALYSIS OF MEDIA LITERACY WITH AGRICULTURAL INFORMATION

\begin{tabular}{|c|c|c|c|}
\hline \multirow[b]{2}{*}{ No. } & \multirow[b]{2}{*}{$\begin{array}{l}\text { Relationship between } \\
\text { Research Variable }\end{array}$} & \multirow{2}{*}{$\begin{array}{c}\text { Pearson Chi-Square } \\
\text { Asymptotic } \\
\text { Significance (2- } \\
\text { sided) }\end{array}$} & \multirow[b]{2}{*}{ Justification } \\
\hline & & & \\
\hline 1. & $\begin{array}{l}\text { Send WhatsApp } \\
\text { messages/chats \& calls in } \\
\text { a Day* Agricultural } \\
\text { Information }\end{array}$ & 0,020 & relate \\
\hline 2. & $\begin{array}{l}\text { Time to Find Information } \\
\text { with WhatsApp * } \\
\text { Agricultural Information }\end{array}$ & 0.030 & relate \\
\hline 3. & $\begin{array}{l}\text { Submitting and } \\
\text { Downloading Farm Info } \\
\text { Videos * Agricultural } \\
\text { Information }\end{array}$ & 0,615 & not relate \\
\hline 4. & $\begin{array}{l}\text { Participate in WA Group } \\
\text { Discussions in a Month * } \\
\text { Agricultural Information }\end{array}$ & 0,008 & relate \\
\hline
\end{tabular}

\section{CONCLUSION}

Characteristics reflect behavior that describes the motivation, personal characteristics, self-concept, values, knowledge or expertise of a farmer to do farming. The relationship between the age factor and Agricultural Information provides findings that the age range of farmers is 20-35 years (productive age category), most of them agree that through WhatsApp they can obtain Agricultural Information. Farmers in the productive category tend to have ease in accepting new things, including technology adoption. Fully aware that agriculture will get added value from the knowledge gained from both formal and informal education. 4 mango farmers known to be elementary school graduates also agreed that WhatsApp was useful for seeking or receiving agricultural information. The findings of this study support various data published by the Indonesian government that the majority of their education is elementary school graduates. However, with the presence of WhatsApp, they have the motivation to seek information to support agricultural activities despite all the existing limitations.

WhatsApp is now an application that is in great demand, especially the ease and completeness of its features. Mango farmers mostly consider WhatsApp to have full features to support searching for agricultural information. Another finding stated that the same number of farmers stated that WhatsApp Icons/Images were easy to remember and found to support the process of searching for agricultural information. Likewise, the ease of navigation between features by farmers is also associated with the process of searching for agricultural information. The results of the chi square analysis of the research variables of information accessibility with agricultural information through WhatsApp describe the expected and factual conditions that are in line. Thus, accessibility of information is a top priority for mango farmers in finding, obtaining, and applying agricultural information using WhatsApp media.

The relationship of Media Literacy with Agricultural Information via WhatsApp shows various results. Manga farmers stated that there was an association between sending messages/chats and WhatsApp calls with Agricultural Information. In addition, it is known that the interesting thing is that the farmers for 1-2 hours is the time that is often used to seek information. On the other hand, mango farmers also stated that agricultural information comes from sending and downloading agricultural info videos. This means that a farmer can act as a recipient of the message as well as a communicator receiving the message. In addition, the research findings interpret the interesting thing that mango farmers who participated in the WA Group discussion in a month agreed, the discussion became a supporting tool for obtaining agricultural information. The results of the chi square analysis of media literacy with agricultural information via WhatsApp can be seen by looking at the significance value approach. The main factors forming Media Literacy with agricultural information through WhatsApp are Sending messages/chats and Calls, Time to Find Information and WhatsApp Group Discussions. Future research can complement this research by using other psychological attributes of farmers to assess the success of using Whatsapp for agriculture. 


\section{REFERENCES}

[1] Nasrullah R. Social Media Perspective of Communication, Culture, and Sociotechnology. Symbiosa Rekatama; Media Publisher Bandung; 2017.

[2] Forbes.com. WhatsApp hits 600 million active users Founder Says [Internet]. 2014. [updated 2014 Aug 25; cited 2021 Jan 9]. Available from: http://www.forbes.com/sites/parmyolson/2014/08/25/whatsapp-hits600-millionactive-users-founder-ays/.

[3] Karapanos, Evangelos, Pedro Teixeira, Ruben Gouveia. Need fulfillment and experiences on social media: A case on Facebook and WhatsApp. Computers in Human Behavior, 2016; 55: 888-897.

[4] Leilani, Ani, Nayu Nurmalia, Muh. Patekkai, 2015. The Effectiveness of Using Extension Media: The Case of the ranca kembang group, luhur jaya village, cipanas district, lebak regency, banten province. Indonesian Journal of Marine and Fisheries Extension, 2015; 9 (1): 43 54.

[5] Malka V, Ariel Y, Avidar R. Fighting, worrying and sharing: Operation 'protective edge' as the first WhatsApp war. Media, War \& Conflict, 2015; 8(3), 329-344. https://doi.org/10.1177/1750635215611610.

[6] Thakur, Devesh, Mahesh Chander, Sushil Sinha. Whatsapp for Farmers: Enhancing the Scope and Coverage of Traditional Agricultural Extension. International Journal of Science, Environment and Technology, 2017:6(4):2190-2201.

[7] Montag C, Zhao Z, Sindermann C, Xu L, Fu M, Li J, Dai J. Internet communication disorder and the structure of the human brain: Initial insights on WeChat addiction. Scientific Reports, 2018; 8(1), 2155. https://doi.org/10.1038/s41598018-19904-y.

[8] Moyo Rachel, Abiodun Salawu, A Survey of Communication Media Preferred by Smallholder Farmers in the Gweru District of Zimbabwe. Journal of Rural Studies, 2019; 66 (2019) 112-118.

[9] Ministry of Agriculture, 2018. Agricultural Sector Employment Statistics 2017 - February 2018. Center for Agricultural Data and Information Systems Secretariat General - Ministry of Agriculture 2018.

[10] Nurgiyantoro, Burhan, Gunawan, Marzuki. Applied Statistics for Research in the Social Sciences: Gadjah Mada University Press. Yogyakarta; 2004.

[11] Zhang Yun, Lei Wang, Yanqing Duan. Agricultural information dissemination using ICTs: A review and analysis of information dissemination models in China. Information Processing in Agriculture, 2016; 3 (2016) 17-29.

[12] Nainggolan Windy A. The Use of WhatsApp as a Media for Agricultural Information: Field Experiments: Members of the Women's Farmers Group, Ciherang Village, Dramaga District, Bogor Regency, West Java Province. Thesis, IPB 2019.

[13] Thakur Devesh, Mahesh Chander, Sushil Sinha. Whatsapp for Farmers: Enhancing the Scope and Coverage of Traditional Agricultural Extension. International Journal of Science, Environment and Technology, 2017; Vol. 6, No 4, 2017, 2190 - 2201.

[14] Vedeld Trond, Mihir Mathur, Neha Bharti. How can co-creation improve the engagement of farmers in weather and climate services (WCS) in India. Climate Services 2019; 15 (2019) 100103.

[15] Shaa Peng, Rayna Sariyskab, René Riedl, Bernd Lachmann, Christian Montag. Linking internet communication and smartphone use disorder by taking a closer look at the Facebook and WhatsApp applications. Addictive Behaviors Reports 2019; 9 (2019) 100148.

[16] Rosenberg H, Asterhan C.S.C. "WhatsApp, Teacher?" - student perspectives on teacher-student whatsapp interactions in secondary schools. Journal of Information Technology Education Research, 2018; 17: 205-226. https://doi. org/10.28945/4081.

[17] Rohi I.R, A. Saleh, R.W.E. Lumintang, The Effectiveness of communication of farmer group opinion leaders in using rice farming technology (Case in Kupang Tengah District, Kupang Regency, NTT). Journal of Development Communication, 2009;07(1). 